\title{
PENDAMPINGAN DAN SOSIALISASI PENANGGULANGAN KEKERASAN TERHADAP ANAK
}

\author{
Dian Novita, Zainuri \\ Fakultas Hukum, Universitas Wiraraja \\ Email : dian.fh@wiraraja.ac.id \\ Email : zainuri@wiraraja.ac.id
}

\begin{abstract}
ABSTRAK
Keberadaan anak merupakan suatu hal yang sangat di harapkan oleh setiap pasangan yang menikah untuk melanjutkan keturunannya, namun tidak semua pasangan dikaruniai generasi penerus .Bagi mereka yang telah mendapatkan keturunan sebagai generasi penerus beraneka ragam pula perlakuan mereka sebagai orang tua terhadap anak-anak mereka..

Ada beberapa permasalahan yang menjadi dasar mengapa perlu direalisasikan pada desa-desa terpencil khususnya pada desa Rubaru kecamatan Rubaru yaitu :

Kurangnya pengetahuan dari para orang tua terkait pentingnya perlakuan baik orang tua terhadap anak anaknya peraturan desa

Sumber daya Manusia orang maupun masyarakat yang terbatas hal ini bisa di lihat dari tingkat pendidikan para orang tua.

Kebiasaan yang di terima oleh para orang tua sejak masa kanak kanak dari orang tua dianggap sudah biasa sehingga perlakuan para orang tua terhadap anaknya juga akan sama seperti yang telah orang tua terima di masa kanak-kanak dahulu.

Kurangnya sosialisasi keberadaan peraturan perundang-undangan terhadap masyarakat.

Berdasarkan permasalah yang terjadi di desa tersebut yaitu desa Rubaru tim Pengabdian berinisiatif untuk mengadakan pendampingan dan sosialisasi terkait penanggulangan kekerasan terhadap anak Langkah awal yang dapat ditawarkan oleh tim adalah memberikan pengetahuan kepada masyarakat desa terkait pentingnya perlakuan yang baik terhadap anak anak sesuai dengan yang di amanahkan oleh undang-undang sekaligus sebagai wujud keperdulian anggota masyarakat terhadap masa depan generasinya dan masa depan bangsa dan negara secara umum di masa yang akan datang.
\end{abstract}

Key word : anak, kekerasan fisik, kekerasan psikis

\section{PENDAHULUAN}

Keberadaan anak merupakan suatu hal yang sangat di harapkan oleh setiap pasangan yang menikah untuk melanjutkan keturunannya, namun tidak semua pasangan dikaruniai generasi penerus seperti yang di harapkan semuanya kembali kepada kehendak Yang Maha Kuasa. Jika dilihat dari besarnya harapan pasangan yang menikah untuk di karuniai anak dalam hidup pernikahannya bisa dilihat semua upaya akan di lakukan agar harapannya bisa terkabulkan walaupun pada akhirnya akan kembali pula kepada kehendak Yang Maha Kuasa. Banyak Bagi pasangan yang diberi kepercayaan untuk memiliki anak dengan mudah namun banyak pula untuk mendapatkan keturunan melalui upaya yang tidak mudah. Bagi mereka yang telah mendapatkan keturunan sebagai generasi penerus beraneka ragam pula perlakuan mereka sebagai orang tua terhadap anakanak mereka. Ada sebagian mereka yang beranggapan bahwa anak mereka merupakan hak milik mereka secara mutlak sehingga para orang tua tersebut merasa bebas untuk memperlakukan anak anak mereka sekendak dan semau mereka, tidak jarang para orang tua bersikap semena mena terhadap anak anak mereka sendiri bahkan anak anak mereka diperlakukan secara tidak berprikemanusiaan. Anak yang mereka miliki tidak dianggap sebagai amanah yang Allah SWT berikan kepada mereka 
melainkan anak anak tersebut dianggap sama dengan barang atau benda yang tidak punya hati dan perasaan yang dapat secara bebas di perlakukan. Perlakuan tidak senonoh kepada anak anaknya tidak hanya berupa perlakuan yang menyakiti fisik semata namun juga perlakuan yang dapat menyakiti psikis seorang anak yang mana anak masih dalam tahap pertumbuhan baik secara fisik maupun psikis dan perlakuan yang di terima oleh anak anak akan tetap terekam seumur hidup mereka dan dapat membentuk karakter hidup mereka dimasa yang akan datang. Keberadaan seorang anak bukanlah semata mata milik dari orang tuanya secara makro keberadaan anak merupakan generasi penerus bangsa ke depan, jika anak di bekali dengan hal hal yang positif saat anak anak maka akan terbentuk karakter yang positif pula di masa tuanya.

\section{Metode}

Berdasarkan permasalahan yang dialami oleh sebagian besar masyarakat, maka Tim berinisiiatif untuk memberikan pendampingan dan penyuluhan hukum berupa sosialisasi penanggulangan kekerasan terhadap anak pada umumnya dan pada khususnya di desa Rubaru kecamatan Rubaru. Tahapan pelaksanaan yang direncanakan antara lain :

\section{Sosialisasi}

Sosialisasi akan segera tim lakukan jika sudah ada kepastian dari pihak LPPM Universitas Wiraraja terkait kegiatan ini dengan meninjau lokasi, sasaran atau mitra sebagai langkah awal di wilayah kegiatan.

2. Penyusunan Materi Penyuluhan

Materi penyuluhan di susun berdasarkan atas keburtuhan program penerapan Pengabdian yang meliputi pentingnya perlakuan orang tua terhadap anak yang berdampak pada fisik dan psikis sang anak dan peningkatan pengetahuan masyarakat pada umumnya.

3. Penyiapan sarana dan prasarana
Sarana dan prasarana yang perlu dipersiapkan dalam kegiatan ini antara lain :

Materi pelatihan, alat peraga penyuluhan, menyiapkan bahan presentasi, dan dokumen lain yang dibutuhkan sebagai dokumentasi kegiatan.

4. Pelaksanaan Pendampingan

Pada masa ini masyarakat akan di beri penyuluhan agar lebih memahami dan jika terjadi permasalahn di belakang hari terkait perlakuan orang tua terhadap anak maka tim selalu siap untuk memberikan pendampingan

\begin{tabular}{|c|c|c|}
\hline No. & Tanggal & Kegiatan \\
\hline 1. & $\begin{array}{l}\frac{a}{0} \\
\frac{0}{\infty} \\
\sum_{0}\end{array}$ & $\begin{array}{l}\text { Tim pengabdian kepada } \\
\text { masyarakat melakukan pertemuan } \\
\text { dengan kepala desa Rubaru terkait } \\
\text { dengan akan dilaksanakannya } \\
\text { kegiatan pendampingan hukum } \\
\text { tentang } \\
\text { penanggulangan } \\
\text { terhadap anak }\end{array}$ \\
\hline 2. & 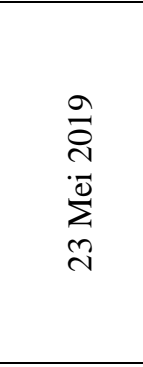 & $\begin{array}{l}\text { Setelah melakukan pertemuan } \\
\text { dengan kepala desa Rubaru, tim } \\
\text { juga mengadakan pendekatan } \\
\text { pada tokoh masyarakat desa } \\
\text { Rubaru dengan menyampaikan } \\
\text { akan mengadakan penyuluhan } \\
\text { hukum dengan maksud ingin } \\
\text { memberikan pemahaman kepada } \\
\text { masyarakat sekitar }\end{array}$ \\
\hline 3. & 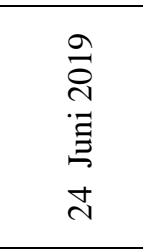 & $\begin{array}{l}\text { Dosen juga melakukan } \\
\text { pendekatan dengan para beberapa } \\
\text { masyarakat Desa Rubaru dengan } \\
\text { menyampaikan niat akan } \\
\text { mengadakan penyuluhan hukum } \\
\text { di RT yang ada di Rubaru }\end{array}$ \\
\hline 4. & 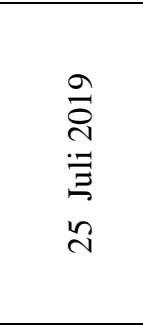 & $\begin{array}{l}\text { Tim Pengabdian } \\
\text { Masyarakat (PKM) kembada } \\
\text { mengadakan pertemuan dengan } \\
\text { perangkat desa dan masyarakat } \\
\text { terkait dengan menentukan waktu } \\
\text { dan tempat kegiatan agar tidak } \\
\text { mengganggu aktivitas masyarakat } \\
\text { sehari-hari. }\end{array}$ \\
\hline 5. & 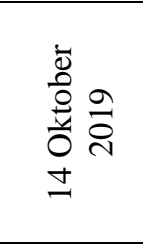 & \begin{tabular}{lr}
\multicolumn{2}{l}{ Pelaksanaan kegiatan penyuluhan } \\
hukum dengan & memberikan \\
pemahaman & tentang \\
pendampingan dan & sosialisasi \\
penanggulangan & kekerasan \\
terhadap anak & \\
\end{tabular} \\
\hline
\end{tabular}




\begin{tabular}{|c|c|c|}
\hline 6. & 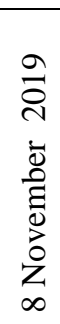 & $\begin{array}{l}\text { Evaluasi pelaksanaan kegiatan } \\
\text { penyuluhan hukum dengan } \\
\text { maksud untuk mengetahui tingkat } \\
\text { pemahaman peserta. }\end{array}$ \\
\hline
\end{tabular}

\section{HASIL DAN PEMBAHASAN}

Pada pelaksanaan pengabdian kepada masyarakat yang dilakukan oleh Tim Dosen dari Fakultas Hukum Universitas Wiraraja menjelaskan tentang pendampingan dan sosialisasi penanggulangan kekerasan terhadap anak.

Banyaknya masyarakat dan aparat desa yang ikut menandakan kami sangat diterima di desa tersebut serta banyaknya pertanyaan - pertanyaan yang diajukan oleh masyarakat terkait dengan Bagaimana yang seharusnya dilakukan oleh masyarakat ataupun apabila terdapat kasus kasus kekerasan terhadap anak.

Harapan kami nantinya setelah selesainya pengabdian kepada masyarakat ini akan mendapatkan hasil yang maksimal yaitu dapat mewujudkan harapan yang tersirat dalam undang-undang nomor 35 tahun 2014 tentang perlindungan anak sehingga anak mendapatkan perlakuan sebagaimana mestinya seorang anak sesuai dengan hak hak yang harus di terima oleh anak.

Faktor Pendorong dan Penghambat

Dari pembahasan tersebut kami mendapatkan beberapa masukan sehingga kami merangkumnya, seperti :

a. Banyaknya masyarakat yang belum mengerti atau tidak mengetahui tata cara bagaimana cara bersikap terhadap anak anak mereka sendiri..

b. Banyaknya masyarakat yang mendidik anak dengan menggunakan pola didik sebagaimana yang telah mereka terima dari orang tua dahulu.

Melalui program Pengabdian maka luaran yang diharapkan adalah sebagai berikut :
1. memberikan pengetahuan bagi masyarakat terkait pentingnya perlakuan orang tua terhadap perkembangan fisik dan psikis anak .

2. Meningkatkan Sumber daya Manusia baik masyarakat yang terbatas menjadi lebih baik demi pembangunan desa ke arah lebih baik secara makro.

3. Memperbaiki kebiasaan lama yang kurang baik yang dianggap biasa menjadi kebiasaan yang lebih baik sesuai dengan perkembangan jaman

4. Membantu pemerintah dalam mensosialisasikan peraturan yang melindungi anak dari tindakan kekerasan yang di lakukan oleh orang orang terdekatnya.

5. Berikut ini 10 penyebab kenakalan remaja yang wajib diketahui orangtua.

\section{Terbiasa dimanja}

Perilaku orang tua yang tidak tepat terhadap anak bisa menjadi pemicu kenakalan pada anak remaja. Hal ini terkadang tak disadari kebanyakan orang tua, salah satunya yaitu anak yang terbiasa dimanjakan dari kecil. Anak-anak yang terbiasa dimanja dan dipenuhi segala keinginannya, sampai ia remaja merasa wajib dipenuhi keinginannya. Kebiasaankebiasaan ini lah yang membuat remaja bertindak semaunya. Sehingga ia bisa melakukan apapun, termasuk berbagai kenakalan.

2. Keluarga tidak harmonisMenurut banyak psikolog, ketidakharmonisan di dalam keluarga menjadi faktor utama penyebab kenakalan pada anak. Orangtua yang sering bertengkar, adanya tindak kekerasan dalam rumah tangga (KDRT) akan memicu agresivitas remaja. Dia akan mencari perhatian dengan melakukan berbagai tindak kenakalan.

\section{Kurangnya kasih sayang}

Penyebab kenakalan remaja lainnya yang sering terjadi adalah kurangnya kasih sayang dari kedua orang tua. Hal ini dapat menjadi pemicu remaja bertindak hal-hal yang tidak baik di lingkungannya. Karena perhatian serta kasih sayang yang kurang, 
membuat anak akhirnya mencari pelampiasan. Salah satunya dengan melakukan kenakalan-kenakalan yang terkadang membuat orang tua merasa jengkel. Kenakalan-kenakalan tersebut mereka lakukan dengan tujuan agar diperhatikan oleh orang tuanya.

4. Pendidikan yang terlalu keras Sebagian orang tua memberikan pendidikan yang keras pada anak dengan harapan, anak mereka tumbuh seperti yang diharapkan. Padahal, pendidikan yang terlalu keras malah akan membuat anak merasa tertekan sehingga memicu sikap memberontak pada orang tua dan lingkungannya.

5. Komunikasi yang buruk .Ketika komunikasi antara orang tua dengan anak terhambat, bisa menjadi penyebab kenakalan-kenakalan yang terjadi pada remaja. Kondisi ini lah yang menyebabkan ketidak terbukaan remaja pada orang tua mengenai masalah-masalah yang sering terjadi. Komunikasi yang terganggu antara anak remaja dan orangtua menyebabkan remaja mencari jati diri di luar, dengan melakukan sejumlah kenakalan di luar rumah.

6. Lingkungan pergaulan.Tak hanya keluarga, lingkungan pergaulan pun bisa menjadi penyebab mengapa remaja dapat berperilaku nakal. Teman-teman yang ada di dalam lingkup permainannya pun bisa menjadi pemicu kenakalan pada anak remaja Anda. Dengan dalih setia kawan, remaja yang masih labil mudah sekali terpengaruh pada hal-hal negatif yang dilakukan temannya.

7. Faktor religi.Setiap orang tua wajib membekali anak-anaknya dengan pendidikan agama. Hal ini karena pendidikan agama merupakan pendidikan dasar yang banyak mengajarkan etika serta moral-moral kehidupan. Sehingga ketika anak-anak tak dibekali dengan pendidikan agama sedari kecil, maka tentu saja akan berakibat buruk pada perilakunya. Anak remaja bisa saja memiliki moralitas yang rendah dan melakukan kenakalan-kenakalan tanpa dipikirkan terlebih dahulu.

8. Lingkungan tempat tinggal. Kondisi dari lingkungan sekitar tempat tinggal juga bisa menjadi penyebab kenakalan pada anakanak remaja. Misalnya saja, ketika ruang lingkup tempat tinggal Anda berada di wilayah yang agamis, maka tentu saja anak remaja Anda akan mengikuti kegiatankegiatan religi yang dilaksanakan di tempat tinggal Anda. Begitupula sebaliknya, jika lingkungan tempat tinggal Anda banyak pelaku tindak kriminal, bisa jadi anak-anak remaja akan terpengaruh. Misalnya mabuk-mabukan, perjudian, pencurian, bahkan narkoba. Waspada selalu ya moms!

9. Faktor ekonomi, Kondisi ekonomi yang kekurangan dapat membuat anak remaja bertindak nakal dan melakukan tindakan kriminal, seperti pencurian. Banyaknya keinginan anak remaja yang tak terpenuhi membuat mereka nekat memenuhi kebutuhan dan keinginannya dengan jalan mencuri.

10. Faktor teknologi informasi, Tak dapat dipungkiri, kemajuan teknologi informasi bak dua mata pisau. Di satu sisi kemajuan bidang teknologi informasi, khususnya sosial media sangat bermanfaat bagi wawasan dan ilmu pengetahuan manusia. Di sisi lain, jika tak disikapi dengan bijak justru akan menghancurkan kehidupan.

Pesatnya informasi yang dengan mudah diakses oleh anak remaja dapat mempengaruhi perilaku keseharian. Bahkan anak remaja akan dengan mudah terpengaruh perilaku pornografi. Dengan kemampuan penyampaian informasi yang dimiliki internet, pornografi pun merajalela. Dengan sekali sentuh, anak remaja dapat menyaksikan adegan pornografi yang seharusnya hanya konsumsi orang dewasa. Tentu saja hal ini berpengaruh buruk pada perilakunya. Kondisi ini memicu hasrat remaja yang tak terkontrol sehingga menyebabkan 
seks di luar nikah (seks bebas), bahkan perkosaan. Mengerikan ya moms?

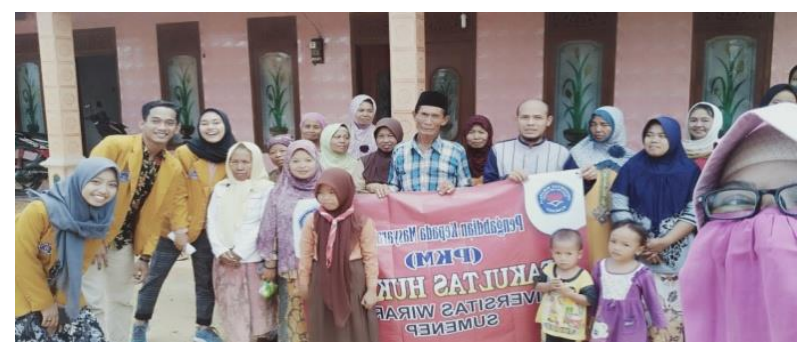

Dokumentasi bersama peserta PKM

\section{Simpulan :}

- Menurut undang-undang nomor 35 tahun 2014 tentang perlindungan anak telah di atur hal hal yang menyangkut perlindungan bagi anak anak agar mendapatkan hak hak seorang anak. Dimana naka merupakan seseorang yang memiliki batasan sampai dengan usia 18 tahun dengan segala hak yang meekat pada diri seorang anak, diantaranya hak untuk bermain, hak Bermain, hak Berkreasi, hak Berpartisipasi, hak Berhubungan dengan orang tua, bila terpisah, hak Bebas beribadah sesuai agamanya, hak Bebas berkumpul, hak Bebas berserikat, hak Hidup dengan orang tua, hak Kelangsungan hidup, tumbuh dan berkembang, dll.

- Dengan hak yang dimiliki oleh seorang anak maka menjadi kewajiban orang tua untuk mewujudkan hak hak yang di miliki oleh seorang anak.

- Dari sekian banyak penyebab kenakalan remaja sebisa mungkin para orang tua untuk meminimalkan bahkan menghindari timbulnya sebab sebab kenakalan remaja tersebut.

\section{DAFTAR PUSTAKA}

Effendi, Lutfi, 2003, Pokok-pokok Hukum administrasi Negara, Malang : Banyumedia Publishing

Jimly Asshiddiqie, 2006, Perihal Undangundang, Jakarta : Konstitusi Pers.

\section{Perundang-undangan :}

Undang-undang nomor 35 tahun 2014 tentang perubahan atas undang-undang nomor 23 tahun 2002 tentang perlindungan anak

Peraturan presiden nomor 61 tahun 2016 tentang komisi perlindungan anak Indonesia 